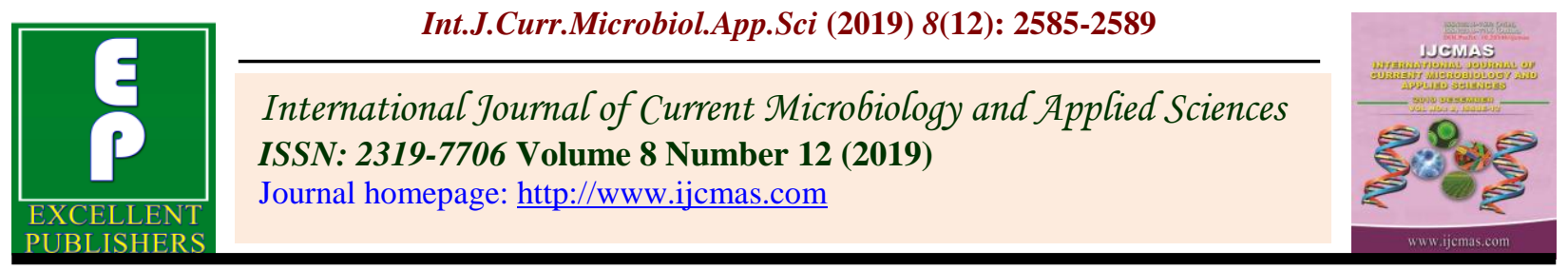

Original Research Article

https://doi.org/10.20546/ijcmas.2019.812.302

\title{
Growth, Yield Parameters and Nutrient Uptake of Roselle as Influenced by Different Genotypes and Fertilizer Levels
}

\author{
M. Raju* \\ Agronomy, Tamil Nadu Rice Research Institute, \\ Aduthurai - 612 101, Thanjavur Dist, India \\ *Corresponding author
}

Keywords

Mesta, Roselle, Variety, Nutrient, Fibre

Article Info

Accepted:

20 November 2019

Available Online:

10 December 2019
A B S T R A C T

A field experiment was conducted during kharif 2017 at Tamil Nadu Rice Research Institute, Aduthurai, Thanjavur District Tamil Nadu to study the growth and yield parameters of mesta as influenced by varieties, and different fertilizers levels. The plant height at harvest stage varied significantly due to different genotypes and fertilizer levels. Among the genotypes, JRHS-1 recorded significantly taller plants $(275.4 \mathrm{~cm})$ than other genotypes. Similar trend was observed under basal diameter. The higher fibre yield of 18.63 q/ha was noticed with JRHS 1 which was higher than other genotypes. Application of 80:17.5:33.3 kg NPK /ha expressed taller plant height, maximum basal diameter which in turn enhanced higher fibre yield of $19.50 \mathrm{q} / \mathrm{ha}$ and at on par with application of $60: 13: 25 \mathrm{~kg}$ NPK/ha (18.84q/ha). However, the benefit cost ratio was more with application of 40:8.7:16.5 kg NPK /ha (1.88) which was almost nearer to application of $60: 13: 25 \mathrm{~kg} \mathrm{NPK} / \mathrm{ha}$ (1.82). It was concluded that the genotypes JRHS 1 was produced higher fibre with application of 60:13:25 $\mathrm{kg} \mathrm{NPK} / \mathrm{ha}$.

\section{Introduction}

Mesta (Roselle: Hibiscus sabdariffa L.) is one of the most important plants of the Malvaceae family. The plant is indigenous to tropic Africa (Kirby, 1963). Roselle is used as fibre, forage and paper pulp and has broadened our agricultural diversity to reduce pressure on forest resources. It is one of the important fibre crops which stand next to jute in production. It is the nearest ally of jute and plays an effective role in supplementing the short supply of jute industry. In recent years, this crop is gaining the attention of research workers since it is also used as a raw material in the paper industry substituting bamboo and 
eucalyptus whose supply is becoming scarce day by day. Mesta fibre is used as an alternative to jute fibre or for blending with jute in the manufacture of jute goods viz., cordage, sackings, hessains, canvas and rough sack cloths. It is also used for making ropes, twines, fishing nets etc. The stalks are used in making paper pulp, structural boards, and blends with wood pulp and for thatching huts. Poor fertilizer management practices also a cause for low yield of roselle. The production of quality roselle fibre in the country is very much essential to meet the increasing demand and expand this valuable crop. Keeping the importance of roselle, research regarding development of new high yielding variety of roselle and optimum fertilizer levels are very important. Therefore, the present study has been undertaken to observe the effects of $\mathrm{N}, \mathrm{P}$ and $\mathrm{K}$ fertilizers on the growth and yield of the pre-released roselle varieties and to obtain highest fibre production.

\section{Materials and Methods}

The field experiment was carried out at Tamil Nadu Rice Research Institute, Aduthurai, Thanjavur during Kharif season 2017 under irrigated conditions. The experimental site was located at $11^{\circ}$ North latitude and $79^{\circ}$ East longitude at an altitude of $19.5 \mathrm{~m}$ above Mean Sea Level (MSL). The region is characterized by a sub-tropical climate with a hot dry summer (March-June), and extended wet period from September to February. Average annual rainfall is about $1078 \mathrm{~mm}$, majority of which was received during North East Monsoon. The soil of the experimental site was clay in texture and moderately drained. The experimental soil was classified as alluvial clay and composed of $13.6 \%$ sand, $61.2 \%$ silt, and $25.3 \%$ clay, $\mathrm{pH} 7.5(1: 5 \mathrm{H} 2 \mathrm{O})$ and EC $11.6 \mathrm{mS} \mathrm{m}^{-1}$ with medium in available nitrogen and phosphorus and high in potassium content.
The experiment was laid out in Factorial Randomized Block Design with three replications. The treatments comprises are such as a. Genotypes (5): JRHS-1 $\left(\mathrm{V}_{1}\right)$, AHS$255\left(\mathrm{~V}_{2}\right)$, JRHS-2 $\left(\mathrm{V}_{3}\right)$, AMV 5( $\left.\mathrm{V}_{4}\right)$ and $\mathrm{H}$ $4288\left(\mathrm{~V}_{5}\right)$ b. Fertilizer levels (4): Control $\left(\mathrm{F}_{1}\right)$, 40:8.7:16.7 kg NPK /ha $\left(\mathrm{F}_{2}\right), 60: 13: 25 \mathrm{~kg}$ NPK /ha $\left(\mathrm{F}_{3}\right)$ and 80:17.5:33.3 $\mathrm{kg}$ NPK /ha $\left(F_{4}\right)$. The seeds of roselle were obtained from National Research Institute for Jute and Allied Fibres, Indian Council Agricultural Research, Kolkata. The seeds of mesta was treated with Mancozeb @ $3 \mathrm{~g} / \mathrm{kg}$ seed against foot and stem rot disease and sown with a spacing of $40 \times 10 \mathrm{~cm}$. Farm yard manure @ $5 \mathrm{t} \mathrm{ha}^{-1}$ was applied during last ploughing. The crop has been maintained by adopting the recommended package of practices. Need based plant protection measures were taken up during crop growth period. At harvest, five plants were selected from each plot in all the 4 genotypes and their replicates and data on plant height, basal diameter and fibre yield were recorded periodically and the data was analysed as per the standard statistical procedures described by Panse and Sukhatme (1985). The crop was harvested when $80 \%$ of the plants showed the sign of maturity. After shedding of leaves, the bundles were steeped plot-wise in pond water for 15-20 days for retting and fiber was extracted. The soil parameters such as $\mathrm{N}, \mathrm{P}$ and $\mathrm{K}$ were analyzed in both situations such as available in soil and uptake by crop.

\section{Results and Discussion}

\section{Growth attributes}

The growth attributes like plant height and stem diameter of mesta varieties as influenced by different nutrient levels at harvest stages of crop growth are presented in Table 1. The plant height at harvest stage varied significantly due to different varieties and nutrient levels. Among the varieties, JRHS-1 
recorded significantly taller plants $(275.4 \mathrm{~cm})$ than other genotypes AHS-255 $(269.4 \mathrm{~cm})$, JRHS-2 $(267.7 \mathrm{~cm})$, AMV $5(260.7 \mathrm{~cm})$ and $\mathrm{H}$ 4288 (268.1). Similarly, higher basal diameter of $1.23 \mathrm{~cm}$ recorded in JRHS-1 followed by JRHS-2 $(1.17 \mathrm{~cm}), \mathrm{H} 4288(1.16 \mathrm{~cm})$, AHS$255(1.13 \mathrm{~cm})$ and AMV $5(1.14 \mathrm{~cm})$ With respect to fertilizer levels, higher dose of 80:17.5:33.3 kg NPK /ha recorded taller plant $(303.4 \mathrm{~cm})$ and higher basal diameter $(1.26$ $\mathrm{cm})$ compared to other fertilizer levels such as 40:8.7:16.7 kg NPK /ha, 60:13:25 kg NPK /ha and No fertilizer of $280.9,1.15 ; 294.1,1.22$ and 194.7,1.03 respectively. It might be due to the initial nutrient supply through inorganic source and later it was from decomposition of FYM, resulting in continuous supply of nutrients to crop. Higher plant height of JRHS-1 variety over AMV-4 could be attributed to their genetic character and longer duration as they belong to $H$. sabdariffa group. Anuradha and Rao (1999), and Sarma
(1999) reported significantly superior fibre yields with new improved varieties over local varieties. Higher biomass production with 'roselle' could be due to its superior genetic potential (Naidu et al., 1996)

\section{Yield attributes}

The genotypes and different levels of fertilizers were significantly influenced on fibre production of mesta. The higher fibre production of $18.63 \mathrm{q} / \mathrm{ha}$ was recorded in JRHS-1 followed by AHS-255 (16.62q/ha), JRHS-2 (16.16q/ha), H 4288 (15.85q/ha) and AMV $5(16.25 \mathrm{q} / \mathrm{ha})$. The higher fertilizer levels, all genotypes were responded positively. Application of $80: 17.5: 33.3 \mathrm{~kg}$ NPK /ha recorded higher fibre yield (19.50q/ha) however it was on par with application of $60: 13: 25 \mathrm{~kg} \quad \mathrm{NPK} / \mathrm{ha}$ $(18.84 \mathrm{q} / \mathrm{ha})$ beyond which the increase was not significant.

Table.1 Growth and yield attributes of roselle influenced by different levels of fertilizers

\begin{tabular}{|c|c|c|c|c|c|c|c|}
\hline Treatments & $\begin{array}{l}\text { Plant } \\
\text { height } \\
(\mathrm{cm})\end{array}$ & $\begin{array}{c}\text { Basal } \\
\text { diameter } \\
(\mathbf{c m})\end{array}$ & $\begin{array}{l}\text { Fibre } \\
\text { yield } \\
\text { (q/ha) }\end{array}$ & $\begin{array}{c}\text { Cost of } \\
\text { cultivation } \\
\text { (Rs./ha) }\end{array}$ & $\begin{array}{c}\text { Gross } \\
\text { return } \\
\text { (Rs./ha) }\end{array}$ & $\begin{array}{c}\text { Net } \\
\text { return } \\
\left(\text { Rs.ha }^{-1}\right)\end{array}$ & B:C \\
\hline \multicolumn{8}{|l|}{ Genotypes } \\
\hline $\mathrm{V}_{1}-\mathrm{JRHS} 1$ & 275.4 & 1.23 & 18.63 & 38350 & 74550 & 36200 & 1.92 \\
\hline$V_{2}-A H S 255$ & 269.4 & 1.13 & 16.62 & 38335 & 73820 & 35485 & 1.90 \\
\hline $\mathbf{V}_{3^{-}}$JRHS 2 & 267.7 & 1.17 & 16.16 & 38420 & 71560 & 33140 & 1.83 \\
\hline$V_{4}-\mathbf{A M V} 5$ & 260.7 & 1.14 & 16.25 & 38510 & 69190 & 30680 & 1.77 \\
\hline$V_{5}-H_{4288}$ & 268.1 & 1.16 & 15.85 & 38080 & 63420 & 25340 & 1.65 \\
\hline SEm \pm & 2.0 & 0.01 & 0.35 & - & - & - & - \\
\hline $\mathrm{CD}(\mathrm{p}=0.05)$ & 5.7 & 0.02 & 1.00 & - & - & - & - \\
\hline \multicolumn{8}{|l|}{$\begin{array}{l}\text { Fertilizer levels: } \\
\text { kg NPK/ha }\end{array}$} \\
\hline $\mathbf{F}_{1}-$ Control & 194.7 & 1.03 & 10.77 & 29408 & 43088 & 13680 & 1.47 \\
\hline$F_{2}-40: 8.7: 16.7$ & 280.9 & 1.15 & 17.70 & 37772 & 70824 & 33052 & 1.88 \\
\hline$F_{3}-60: 13: 25$ & 294.1 & 1.22 & 18.84 & 42165 & 76600 & 34435 & 1.82 \\
\hline$F_{4^{-}}$80:17.5:33.3 & 303.4 & 1.26 & 19.50 & 43510 & 78024 & 34514 & 1.79 \\
\hline SEm \pm & 1.8 & 0.01 & 0.32 & - & - & - & - \\
\hline $\mathrm{CD}(\mathrm{p}=0.05)$ & 5.1 & 0.02 & 0.91 & - & - & - & - \\
\hline
\end{tabular}


Table.2 Available nutrient status of soil and nutrient uptake by roselle

\begin{tabular}{|c|c|c|c|c|c|c|}
\hline \multirow[t]{2}{*}{ Treatments } & \multicolumn{3}{|c|}{ Available nutrient at harvest (kg/ha) } & \multicolumn{3}{|c|}{ Nutrient uptake (kg/ha) } \\
\hline & $\mathbf{N}$ & $\mathbf{P}_{2} \mathbf{O}_{5}$ & $\mathrm{~K}_{2} \mathrm{O}$ & $\mathbf{N}$ & $\mathbf{P}_{2} \mathbf{O}_{5}$ & $\mathbf{K}_{2} \mathbf{O}$ \\
\hline \multicolumn{7}{|l|}{ Genotypes } \\
\hline $\mathbf{V}_{1}-$ JRHS 1 & 175.97 & 41.75 & 113.20 & 42.56 & 19.77 & 26.80 \\
\hline $\mathrm{V}_{2}-\mathbf{A H S} 255$ & 176.35 & 41.84 & 110.79 & 42.30 & 20.73 & 28.50 \\
\hline $\mathbf{V}_{3^{-}}$JRHS 2 & 178.01 & 41.96 & 109.86 & 39.76 & 18.47 & 26.16 \\
\hline $\mathrm{V}_{4}-\mathrm{AMV} 5$ & 181.50 & 43.17 & 111.28 & 40.47 & 18.46 & 27.46 \\
\hline$V_{5}-H_{4288}$ & 182.85 & 42.40 & 117.44 & 39.15 & 19.81 & 25.36 \\
\hline SEm \pm & 0.85 & 0.26 & 0.75 & 0.50 & 0.28 & 0.32 \\
\hline$C D(p=0.05)$ & 2.43 & 0.74 & 2.14 & 1.43 & 0.80 & 0.91 \\
\hline \multicolumn{7}{|l|}{$\begin{array}{l}\text { Fertilizer levels: } \\
\text { kg NPK /ha }\end{array}$} \\
\hline $\mathbf{F}_{1}-$ Control & 174.81 & 39.77 & 106.93 & 38.27 & 17.65 & 25.07 \\
\hline$F_{2}-40: 8.7: 16.7$ & 177.11 & 41.55 & 112.32 & 39.65 & 18.78 & 26.08 \\
\hline$F_{3}-60: 13: 25$ & 179.41 & 42.99 & 114.43 & 40.52 & 20.15 & 27.29 \\
\hline $\mathbf{F}_{4}-80: 17.5: 33.3$ & 184.42 & 44.58 & 116.38 & 44.95 & 21.22 & 28.98 \\
\hline SEm \pm & 0.76 & 0.23 & 0.67 & 0.45 & 0.25 & 0.29 \\
\hline$C D(p=0.05)$ & 2.17 & 0.65 & 1.91 & 1.28 & 0.71 & 0.82 \\
\hline
\end{tabular}

The interaction of genotypes and fertilizer levels on fibre yield of roselle was found non significant effect. Higher fibre with the application of $80: 17.5: 33.3 \mathrm{~kg} \mathrm{NPK} / \mathrm{ha}$ and 60:13:25 kg NPK /ha could be attributed to increased plant height and basal diameter of the test varieties (Table 2). The results obtained confirm the findings of Biwas (2004) and Venkatakrishnan et al., (2004).

Available nutrient in soil and nutrient uptake by crop

The roselle genotypes JRHS -1 and AHS 255 recorded significantly higher nitrogen and phosphorus uptake over other genotypes while potassium uptake was significantly higher with AHS 255 only. As a result, the available nutrient content of the experimental soil was lesser with the test entries compared to the check varieties (AMV 5 and $\mathrm{H}$ 4288). Nutrient uptake by roselle and available nutrient status of soil increased with fertilizer application and maximum value of the said parameters were observed in the highest dose of fertilizer level. In case of economics, the test entry JRHS 1 recorded highest gross return (Rs.74550/ha), net return (Rs.36200/ha) and B:C ratio (1.92) followed by other entries. Maximum gross and net return were recorded with highest fertilizer dose of $80: 17.5: 33.3 \mathrm{~kg}$ NPK /ha while maximum $\mathrm{B}: \mathrm{C}$ ratio (1.87) with 40:8.7:33.3 $\mathrm{kg} \mathrm{NPK} /$ ha fertilizer dose.

In conclusion, the results of study on effect of genotypes under different fertilizer levels revealed that the growth and yield attributes of roselle were significantly influenced by factors studied. Thus, it may be concluded that application of $60: 13: 25 \mathrm{~kg} \mathrm{NPK} /$ ha for JRHS 1 produced higher fibre yield which also gave higher net return. Therefore, it is recommended to farmers for adopt the fertilizer level of 60:13:25 $\mathrm{kg} \mathrm{NPK} / \mathrm{ha}$ in roselle for better yield and income. 


\section{References}

Anuradha, T., and Rao, V. M. (1999). Phenotypic stability of fibre yield in mesta (Hibiscus sabdariffa L.). The Andhra Agril. J., 46(1), 85-86.

Biwas, J. (2004). The world major fibre crops, their cultivation and manuring (pp. 227-231). Centre D' Etude de I'Azote, Zurich.

Donald, C. M. (1962). In search of yield. J. Aust. Inst. Agric. Sci., 28, 171-178.

Naidu, M. V., Prasad, P. R., and Lakshmi, M. B. (1996). Influence of species, fertility level and stage of harvest on biomass production and pulp yield in mesta (Hibiscus sp.). J. Res., ANGRAU, 24(3), 1-4.

Sarma, T. C. (1999). Effect of nitrogen on pulpable biomass yield of roselle (Hibiscus sabdariffa). Indian J. Agron., 44(1), 185-186.

Venkatakrishnan, A. C., Bharathi L. M., Vanku N. M., Srinivasulu R. D., \& venkatareddy, C. (2004), Effect of time sowing and topping on seed yield of roselle (Hibiscus sabdariffa). Indian J. Agron., 40(4), 682-685.

\section{How to cite this article:}

Raju, M. 2019. Growth, Yield Parameters and Nutrient Uptake of Roselle as Influenced by Different Genotypes and Fertilizer Levels. Int.J.Curr.Microbiol.App.Sci. 8(12): 2585-2589. doi: https://doi.org/10.20546/ijcmas.2019.812.302 